\title{
BUJUKAN BERWISATA KE BALI: SIMBOL-SIMBOL PROMOSI PARIWISATA FILM ‘EAT PRAY LOVE’
}

\author{
Rimalinda Lukitasari dan I Nyoman Darma Putra \\ Universitas Udayana
}

\begin{abstract}
Film is a potential tourism promotion since the symbols and meanings in it have the capability in influencing the responses of the audiences and motivating them to visit the location that being featured. Indonesia has also experienced the tourism promotion benefits as a result of the popularity of a film, however, the studies in this field have not been gaining much attention yet. This research was aimed to study the tourism promotion through film by analyzing the symbols and meanings in the film 'Eat Pray Love' that conveys the rational, emotional, and moral appeals. The analyses were conducted by using qualitative method and applying the semiotics theory. The results show that the atmosphere of Bali is well captured in the film, which lead to some hints of Bali as a good tourist destination. These hints consist of rational, emotional, and moral appeals. The rational appeals in the film are related to the sensory benefits, security, sanitation, and good accesibilty. The emotional appeals suggest Bali as a relaxing, beautiful, romantic, and friendly destination. The moral appeal shows an encouragement come to Bali to find guidances toward spiritual balance.
\end{abstract}

Keyword: yourism promotion, film, Eat Pray Love, Bali.

\begin{abstract}
Abstrak
Film merupakan sebuah promosi pariwisata yang potensial sebab simbol dan makna dalam film memiliki kemampuan mempengaruhi respon penonton dan memotivasi mereka untuk mengunjungi lokasi yang ditampilkan. Indonesia juga telah mendapatkan manfaat promosi pariwisata sebagai hasil dari popularitas sebuah film, namun, kajian di bidang ini belum mendapatkan banyak perhatian. Penelitian ini ditujukan untuk mempelajari promosi pariwisata melalui film dengan menganalisis simbol dan makna dalam film 'Eat Pray Love' yang menghadirkan daya tarik rasional, emosional, dan moral. Analisis dilaksanakan dengan menggunakan metode
\end{abstract}


kualitatif dan menerapkan teori semiotika. Hasil penelitian menunjukkan bahwa atmosfer Bali ditangkap dengan baik dalam film, sehingga memberikan beberapa petunjuk mengenai Bali sebagai tempat tujuan wisata yang baik. Petunjuk-petunjuk ini terdiri dari daya tarik rasional, emosional, dan moral. Daya tarik rasional dalam film berhubungan dengan manfaat sensorik, keamanan, kebersihan, dan aksesibilitas yang baik. Daya tarik emosional memberikan pandangan Bali sebagai destinasi yang menenangkan, indah, romantis, dan ramah. Daya tarik moral memperlihatkan dorongan untuk datang ke Bali untuk menemukan bimbingan menuju keseimbangan spiritual.

Kata kunci: promosi pariwisata, film, Eat Pray Love, Bali

\section{Pendahuluan}

Promosi merupakan kegiatan yang sangat penting dalam suatu proses pemasaran destinasi pariwisata. Banyaknya kompetitor suatu destinasi juga dapat menjadi alasan kuat mengapa kegiatan promosi menjadi bagian yang tidak dapat ditinggalkan. Promosi persuasif merupakan tindakan penting saat suatu produk memiliki pesaing-pesaing. Persuasi (bujukan) untuk memilih dan menggunakan suatu produk, dalam media promosi dapat dilakukan dengan memunculkan daya tarik rasional, emosional, atau moral (Kotler dkk, 2010).

Kim (2012) menjelaskan bahwa konsumsi manusia terhadap media visual semakin berperan dalam membentuk persepsi terhadap stereotipe suatu tempat, sehingga muncul imajinasi dan ekspektasi mengenai hal-hal yang akan ditemui di suatu destinasi pariwisata. Sharon (1992) mengatakan bahwa "One major reason for travelling, and for selecting a particular destination, is to see something about which we have read or heard for a long time" (Satu alasan utama untuk bepergian, dan dalam memilih suatu destinasi tertentu, adalah untuk melihat sesuatu yang berkaitan dengan hal yang kita pernah baca atau dengar pada jangka waktu yang lama).

Sebagai media audio-visual yang dapat menyampaikan cerita, film dapat menjadi media promosi yang potensial. Vagionis dan Loumioti (2011) mengatakan bahwa prinsip penyisipan pesan-pesan promosional dalam film untuk mengunjungi destinasi pariwisata berlaku seperti halnya peletakan produk (product placement). Ketidaksadaran akan adanya pesan promosi dalam film menjadikannya alat komunikasi yang efektif. Pembentukan citra yang ditimbulkan oleh tokoh dan cerita menjadikan efek film tetap efektif menarik wisatawan bahkan setelah beberapa tahun setelah penayangan awal. Connell (2012: 1014) menjelaskan bahwa muatan makna dan simbol 
yang memenuhi suatu film memungkinkan untuk menimbulkan kemampuan untuk mempengaruhi respon penonton dalam suatu kerangka sistem sosial dan budaya tertentu sehingga dapat berpotensi menimbulkan kesadaran dan ketertarikan terhadap lokasi pembuatan film.

Bali beruntung beberapa kali diangkat sebagai latar atau tema film nasional dan internasional. Hal ini sudah terjadi sejak tahun 1930-an, sebelum kemerdekaan. Tahun 1930, film "Goona-goona” menjadi tonggak awal ketenaran Bali di dunia barat (Bali Echo, 2001). Belakangan ini, Bali kembali diuntungkan oleh keberadaan film 'Eat Pray Love' pada tahun 2010 yang salah satunya mengambil latar di Ubud.

Ulasan-ulasan pada sejumlah media memperlihatkan adanya indikasi kenaikan jumlah wisatawan di Ubud yang berkaitan dengan keberadaan film 'Eat Pray Love' ini (Daily Mail, 2010; Denver Post, 2010; The Jakarta Post, 2010; Time, 2010). Melihat pada hal ini dapat dikatakan bahwa simbolsimbol yang hadir dalam film 'Eat Pray Love' memiliki dampak promosi bagi pariwisata di Bali. Walaupun film merupakan salah satu media promosi pariwisata yang potensial, namun kajian di bidang ini masih sangat kurang dilakukan di Indonesia.

Artikel ini mengkaji bentuk promosi pariwisata melalui film dengan menganalisis konten film 'Eat Pray Love' dalam konteks simbol-simbol yang memuat bujukan yang bersifat rasional, emosional dan moral secara semiotika. Diharapkan pembahasan dalam artikel ini dapat menjadi referensi dalam pemanfaatan film sebagai media promosi pariwisata di masa mendatang.

\section{Teori dan Metode}

Penelitian ini dilaksanakan secara kualitatif-interpretif dengan menggunakan teori semiotika untuk menganalisis makna simbol-simbol promosi pariwisata dalam film 'Eat Pray Love'. Semiotika merupakan "ilmu tentang tanda dan kode-kodenya serta penggunaannya dalam masyarakat” (Piliang (2010: 19). Menurut Barthes (dalam Piliang 2012), proses interpretasi dilakukan secara bertingkat, yaitu denotasi sebagai makna tingkat pertama dan konotasi sebagai makna tingkat kedua. Makna denotasi merujuk pada kode-kode yang memperlihatkan hubungan antara penanda (signifier) dan petanda (signified) yang eksplisit. Sedangkan, makna konotatif sebagai makna tingkat kedua menghadirkan sistem kode yang maknanya implisit dimana pemaknaannya berkaitan dengan aspek-aspek psikologis. Makna konotatif ini berada pada kawasan ideologi atau mitologi yang mendapatkan maknanya dari hasil serangkaian kode yang berlaku dan disepakati bersama. Ideologi yang dimaksud adalah sistem gagasan, ide, atau kepercayaan yang sudah menjadi konvensi pada suatu masyarakat. Jika suatu hal yang bersifat konotatif dikodekan secara berlebihan sehingga 
tampak natural maka makna tersebut menjadi mitos (Piliang, 2012; Thwaites dkk., 2011: 108, 119).

Makna yang diungkapkan dalam penelitian ini adalah makna denotatif dan konotatif dalam konteks daya tarik rasional, emosional, dan moral. Ketiga daya tarik tersebut dihubungkan dengan promosi persuasif untuk pariwisata Bali yang ditampilkan dalam film.

Daya tarik rasional mengetengahkan manfaat yang dimiliki oleh produk berkenaan dengan minat calon konsumen. Bentuk informasi-informasi yang dapat digunakan sebagai daya tarik rasional antara lain berkenaan dengan kualitas, daya guna, kenyamanan, ekonomi, kesehatan, relaksasi, dan manfaat-manfaat sensorik. Provokasi emosional dapat dilakukan dengan menampilkan pesan yang menyentuh emosi seperti ketakutan, rasa bersalah, dan rasa malu, cinta, kasih sayang, maupun hal-hal yang berhubungan dengan minat, status, dan pengakuan umum, yang dapat memotivasi seseorang untuk melakukan atau tidak melakukan suatu kegiatan.

Daya tarik emosional dapat diaplikasikan berupa bentuk promosi yang menghibur, menarik, menimbulkan gairah, membangkitkan semangat dan bentuk-bentuk lain yang mempengaruhi emosi konsumen dan mendorong mereka untuk memiliki pandangan positif terhadap suatu produk.

Daya tarik moral menganjurkan kepada hal-hal yang benar dan pantas untuk dilakukan. Daya tarik moral ini banyak digunakan untuk mempromosikan kegiatan-kegiatan lingkungan hidup (Kotler dkk, 2010; Morissan, 2010).

Proses intepretasi ini juga akan diuji dengan mengikuti sembilan kaidah yang diajukan oleh Purwasito (2005) yaitu dengan menguji berdasarkan konvensi masyarakat dengan melihat latar belakang corak ideologi pelaku komunikasi, dengan melihat konteks penggunaan tanda, dengan melihat kaitan dengan tanda-tanda lainnya, dengan melihat fungsi tanda yang bersangkutan dalam masyarakat, dengan melihat teks-teks yang berkaitan, dengan melihat penafsiran dari penafsir lain (penonton dan wisatawan), dengan melihat pada pendapat penafsir berpengalaman dalam bidang yang berkaitan, dan berdasarkan tafsir intuitif peneliti berdasarkan pada pengalaman intelektual.

Data yang digunakan dalam penelitian ini adalah data primer dan sekunder. Data primer berupa film 'Eat Pray Love' dalam bentuk DVD, sedangkan data sekunder meliputi komentar-komentar penonton dan wisatawan yang dikumpulkan dari laman peninjau film Rotten Tomatoes dan IMDb, serta beberapa blog perjalanan yang memberikan tinjauan secara independen. Komentar-komentar tersebut dikumpulkan secara purposive untuk mendukung proses interpretasi terhadap simbol-simbol dalam film. 


\section{Film 'Eat Pray Love'}

'Eat Pray Love' merupakan film yang diadaptasi dari novel berjudul sama karya Elizabeth Gilbert dan diproduksi oleh Columbia Picture bekerja sama dengan Plan B Entertainment. Narasi dalam film ini berdasarkan kisah nyata perjalanan seorang penulis bernama Elizabeth Gilbert atau biasa dipanggil Liz (dimainkan oleh Julia Robert) ke tiga negara, Italia, India, dan Indonesia, dalam menemukan kembali keseimbangan dan gairah hidup dalam dirinya yang telah lama hilang (IMDb, 2010a).

Perjalanan Liz, wanita Amerika, dimulai dari Italia dimana dia banyak menghabiskan waktunya untuk berwisata kuliner sambil belajar bahasa Italia. Adegan-adegan di Italia banyak menampilkan gambar-gambar makanan yang secara fotografis menggugah selera.

Perjalanan selanjutnya dilakukan di India, diisi adegan dengan gambaran lalu lintas India yang semrawut dan sampah di pembatas jalan. Adeganadegan di India banyak dilakukan di dalam Ashram tempat Liz menghabiskan waktunya untuk kegiatan meditasi yang serius, pekerjaan pelayanan untuk membersihkan kuil, dan belajar kitab Guru Gita.

Perjalanan Liz diakhiri di Bali, tempat Liz kembali menemui Ketut Liyer yang sebelumnya pernah meramal masa depannya. Di bawah bimbingan pelamar Ketut Liyer, Liz belajar membuat kesimpulan dari pengalaman perjalanannya ke dua negara sebelumnya dengan cara melakukan meditasi di pagi hari, menikmati Bali di siang hari, dan bermeditasi tersenyum ala Ketut Liyer di sore hari.

Di Bali, Liz dilukiskan bertemu dan jatuh cinta dengan seorang lelaki Brazil yang kemudian diceritakan menjadi pelengkap keseimbangan spiritual yang selama ini dicarinya.

\section{Bujukan untuk Mengunjungi Bali}

Pada film 'Eat Pray Love', simbol-simbol yang mewakili pesona pariwisata Bali, atraksi wisata, dan muatan lokal yang dapat menjadi deferensiasi produk wisata ditampilkan melalui aspek naratif dan sinematik. Bali yang ditampilkan dalam film ini bukan hanya indah dipandang mata, bersih, nyaman, namun juga santai, eksotik, dan romantis dengan muatan kearifan lokal Bali yang unik.

Citra pariwisata Bali yang selama ini banyak dikenal dengan keindahan pantai serta kegiatan-kegiatan yang berhubungan erat dengan sea, sand, sun, dan pesta-pesta, pada film ini dilengkapi dengan menampilkan nuansanuansa pariwisata yang lebih hijau, tenang, dan berkesan spiritual. Sebuah paket wisata spiritual di Bali juga menyebutkan wisata ala 'Eat Pray Love' sebagai suatu kegiatan wisata yang menikmati Bali seperti warga lokal (Spirit Quest Tour, t.t). Hal ini menunjukkan bahwa film 'Eat Pray Love' juga memunculkan simbol-simbol muatan lokal yang berkaitan dengan 
pengalaman cultural contact dalam kegiatan berwisata. Penampilan pesona wisata Bali dalam film 'Eat Pray Love' ini memuat adanya promosi persuasif yang mengetengahkan manfaat-manfaat berwisata di Bali yang ditampilkan dalam bentuk bujukan rasional, emosional, dan moral secara metafora.

\subsection{Bujukan Rasional pada Film 'Eat Pray Love'}

Bujukan yang memperlihatkan daya tarik rasional dalam film ini timbul dari adanya simbol-simbol yang menunjukkan adanya manfaat sensorik yang mendukung suasana nyaman, seperti udara yang sejuk dan lingkungan yang tenang, kemudian dengan adanya petunjuk aksesibilitas yang baik, kebersihan, dan keamanan. Udara yang sejuk tersimbolkan dari penggambilan gambar pada lokasi-lokasi yang terlihat rimbun dan penggambaran adegan tokoh Liz ketika bersepeda. Saat bersepeda tentunya seseorang berkeringat, namun tokoh Liz diperlihatkan tetap segar walaupun sudah bersepeda. Adegan bersepeda juga memperlihatkan hembusan angin sepoi-sepoi yang menerpa rambut tokoh Liz. Simbol udara sejuk juga dipertegas dengan penggunaan pakaian cardigan oleh tokoh Liz, yang menunjukkan bahwa walaupun sudah bersepeda dengan menggunakan dua lapis baju Liz tidak terlihat kegerahan. Kegiatan bersepeda ini juga sekaligus memperlihatkan adanya fasilitas akses jalan yang baik dan bersih di Ubud. Lingkungan tenang dapat dilihat secara jelas saat Liz melakukan kegiatan meditasi di bungalow yang terletak di tengah persawahan. Pada adegan tersebut tidak diaplikasikan musik, namun justru memperdengarkan noise suara sekitar yang memperdengarkan suara kicau burung secara lirih.

Daya tarik rasional dalam hal keamanan diwakilkan oleh dua hal, yaitu lingkungan yang aman dari tindak kejahatan dan makanan-minuman yang aman untuk dikonsumsi. Aman dari tindak kejahatan tersimbolkan pada adegan yang memperlihatkan Liz yang tinggal sendirian di sebuah penginapan yang terletak di tengah persawahan dengan akses masuk berupa jalan setapak kecil. Bagi penonton yang terbiasa hidup di tengah modernisasi, tempat tinggal di tengah-tengah sawah yang mungkin bahkan tidak muncul dalam aplikasi peta Google Maps, dapat nampak seperti lokasi di antah berantah dimana seseorang harus waspada, terutama bagi wanita yang bepergian sendirian. Tapi, dalam film diperlihatkan bahwa Liz tinggal dengan baik-baik saja di penginapan tersebut. Pada adegan lain setelah adegan di atas, bahkan diperlihatkan Liz tertidur pulas dengan pintu kamar terbuka lebar. Ini memberikan kesan bahwa lingkungan tersebut cukup aman.

Keamanan makanan dan minuman di Bali disimbolkan pada film ini pada adegan Felipe datang ke penginapan Liz membawakan minuman penawar mabuk buatan Wayan yang dikemas dalam sebuah kantong plastik dengan sebuahsedotan didalamnya.Gambaran minuman dengankemasan sederhana 
tersebut dapat memunculkan kesan tidak higienis, namun penempatan pada narasi dimana Felipe membawakan minuman tersebut kepada Liz tanpa ada 'embel-embel' peringatan mengenai higienitas seolah menggaransi bahwa minuman tersebut aman walaupun kemasannya sederhana. Hal ini kontras jika diambil perbandingan dengan minuman kemasan dalam botol yang diminum Liz di India. Pada minuman 'Thumps Up' di sekuen India, melekat peringatan Richard bahwa seseorang harus selalu minum dengan sedotan jika hendak meminum sesuatu di India. Kalimat ini menjadi simbol adanya kekawatiran mengenai higienitas kemasan minuman di India walaupun dikemas dalam wadah yang terlihat bersih dan layak.

Perbandingan dengan dua destinasilainnya, Italia dan India, menunjukkan daya tarik rasional yang mengetengahkan keunggulan banding Bali sebagai sebuah destinasi yang berkaitan dengan harga, kebersihan, dan ketertiban. Perjalanan Liz dikisahkan sebagai perjalanan berbiaya rendah. Dengan dana terbatas, di Italia Liz mendapatkan penginapan dengan bangunan lawas tanpa adanya akses air panas yang cukup. Sedangkan, penginapan di Bali diperlihatkan sebagai villa yang terdiri dari dua bangunan bungalow, bersih, terlihat nyaman, dan berfasilitas cukup lengkap. Perbandingan dengan India utamanya menegaskan lingkungan Bali yang lebih bersih, sebab lingkungan di India diperlihatkan kotor dengan lalu lintas yang padat dan tidak teratur. Simbol-simbol kebersihan di Bali tidak hanya muncul pada gambaran jalanan yang bersih, namun juga diperlihatkan pada gambar suasana anak-anak yang sedang mandi di sungai. Penampilan anak-anak yang mandi di sungai yang terlihat bersih juga memberikan suatu indikasi bahwa lingkungan di sekitarnya tidak tercemar.

Penampilan diferensiasi wisata spiritual di Bali dapat dikatakan merupakan daya tarik rasional, sebab mengetengahkan manfaat produk pariwisata yang dapat diperoleh di Bali. Secara naratif, keyakinan Liz mengenai jawaban yang akan ditemukannya di Bali, serta cara kepercayaan diri Ketut Liyer bahwa dia mampu membimbing Liz juga menjadi daya tarik rasional yang mengetengahkan kepercayaan terhadap produk pariwisata spiritual di Bali. Demikian pula cara Wayan Nuriasih dalam meyakinkan Liz bahwa jamu lebih baik dari obat.

\subsection{Bujukan Emosional pada Film 'Eat Pray Love'}

Bujukan yang mengetengahkan daya tarik emosional pada film ini muncul dari sisi sinematik dan narasi yang disajikan dengan baik, sehingga penonton secara emosional dapat ikut merasakan suasana liburan di Bali, secara metafora, seperti sedang berada di lokasi (IMDb, 2010b; IMDb, 2010c). Penggambaran tersebut termasuk dari sisi sinematografis, pengaplikasian suara, dan akting pemain. Film 'Eat Pray Love' menangkap dengan baik atmosfer liburan yang santai, damai, dan beritme lambat namun tidak lesu 
tersebut. Selain itu terdapat muatan emosional yang berasal dari kearifan lokal Bali. Secara naratif, kisah perjalanan Elizabeth Gilbert dalam mencari keseimbangan spiritual menampilkan daya tarik emosional yang membuat penonton juga termotivasi untuk melakukan perjalanan pada umumnya, dan datang ke Bali secara khususnya. Hasil dari adanya daya tarik emosional dalam narasi dapat juga dapat dilihat dari adanya wisatawan-wisatawan perempuan yang mengikuti jejak Elizabeth Gilbert. (IMDb, 2010d; $I M D b$, 2010e; Jezebel, 2010; Rotten Tomatoes, 2010a; Rotten Tomatoes, 2010b; Rotten Tomatoes, 2010c; World Toddler, 2016)

Sesuai dengan pendapat Morissan (2010) bahwa provokasi emosional dapat dimunculkan dengan cara mendorong penonton untuk memiliki pandangan positif terhadap suatu produk, maka penampilan suasana Bali dalam film cenderung menunjukkan simbolisme Bali yang indah dan asri, serta santai dan bebas stress. Simbolisme ini hadir baik secara visual maupun audio. Gambar banyak diambil secara jarak jauh maupun bird eye view yang antara lain memperlihatkan air pantai dan riak-riak ombak yang dibarengi lirih suara deburan ombak, kemudian pemandangan gunung dengan sedikit awan dan hamparan rimbun puncak-puncak pepohonan kelapa, terasering sawah yang baru tanam, serta perkebunan kelapa yang subur dan hijau. Pada musik latar (non diagetic) terdengar alunan-alunan musik yang cenderung bernuansa santai namun juga memunculkan bagianbagian ceria yang eksotik. Film ini memanfaatkan musik gending Bali yang diorkestrasikan dengan alat musik modern dalam komposisi yang mengalun dengan tempo sedang, dan juga memunculkan lagu bernuansa bossanova untuk membangun suasana. Gambar pemandangan dan musik yang santai menjadi pendamping untuk adegan-adegan yang memperlihatkan tokoh Liz Gilbert (Julia Robert) yang selalu menikmati perjalanan bersepedanya di Bali.

Pengambilan gambar pemandangan yang dilakukan dengan jarak jauh memungkinkan pemandangan asri di destinasi tertangkap dengan lebih utuh. Pengambilan gambar dengan cara ini dapat menyimbolkan adanya kesan luas dan lega. Pengambilan gambar juga banyak dilakukan secara kontinu disertai oleh alunan musik latar yang mengalun tanpa hambatan dan ceria. Musik yang mengalun tanpa hambatan tersebut memberikan simbolisasi suasana bebas stres dan santai. Hal ini menguatkan kesan rileks pada suasana yang ditampilkan di depan layar. Akting Julia Robert yang sedang bersepeda sambil memperlihatkan wajah tersenyum sambil memandang kanan kirinya juga menjadi simbolisasi untuk suasana nyaman dan menyenangkan dan cenderung santai yang sedang dinikmatinya.

Film 'Eat Pray Love' ini juga memperlihatkan kemampuan menangkap keutuhan suasana. Suara lirih kicau burung dan suara bebek yang digiring di jalanan kecil memberikan kesan suasana pedesaan yang masih asri 


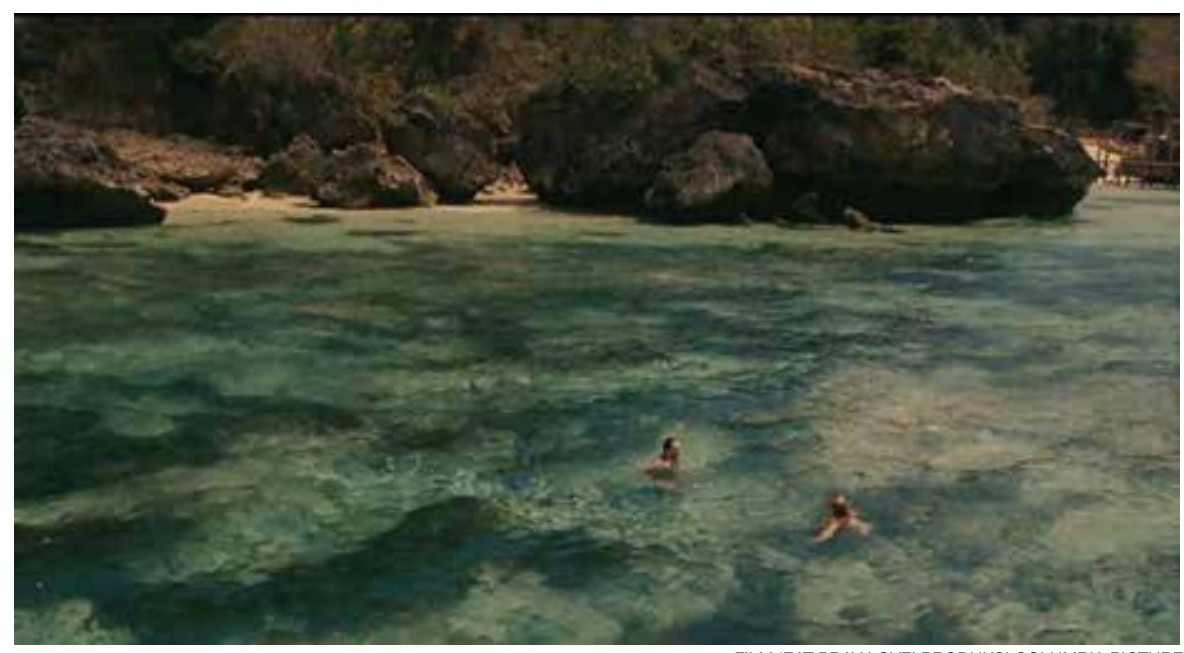

FILM 'EAT PRAY LOVE' PRODUKSI COLUMBIA PICTURE

Gambar 5.1 Shot Felipe dan Liz berenang di pantai

dan asli. Jalanan yang sepi kendaraan juga menambah petunjuk suasana pedesaan di lokasi yang bersangkutan masih belum banyak terkontaminasi oleh kesibukan lalu lintas kota modern. Detail-detail yang disajikan dalam film 'Eat Pray Love' ini menjadi provokasi emosional yang membantu penonton untuk benar-benar tertransportasi ke dalam film dan seolah-olah ikut menjalani liburan tersebut bersama tokoh dalam cerita. Pengalaman tertransportasi ini diungkapkan juga oleh penonton dalam komentarnya di laman IMDb dengan mengatakan bahwa "the atmospheres of Italy, India and Bali were all brought to life" (atmosfer Italia, India dan Bali semuanya dibuat hidup) (IMDb, 2010b).

Bali tentunya tidak lengkap tanpa memperlihatkan pantai. Suasana pantai yang diperlihatkan di film ini merupakan pantai yang masih asli dan "perawan". Daya tarik emosional pada adegan pantai muncul pada pengambilan gambar yang memperlihatkan air laut yang biru dan jernih, ekspresi akting kedua pemeran yang berenang dengan gembira, serta musik latar yang memperdengarkan musik dengan sentuhan kelompok instrumen musik tiup dengan tempo sedang-cepat berintonasi ceria. Keberadaan musik tersebut menguatkan daya tarik yang memperlihatkan betapa menyenangkannya berenang di pantai itu. Adegan sepasang laki-laki dan perempuan yang sedang berenang sambil saling menggoda ditambah dengan musik latar yang berkesan ceria dan bersemangat tersebut juga menjadi suatu daya tarik emosional yang bekerja dengan cara membangkitkan gairah (Gambar 5.1).

Adanya kisah percintaan di dalam film bertema travelogue ini, juga memberikan daya tarik emosional dari segi narasi berupa romatisme. Adegan-adegan Liz dengan Felipe dan narasi tokoh Liz yang menemukan 
cinta di Bali dapat menjadi simbolisasi romantisme. Simbol romantisme juga dapat muncul dari kalimat "everybody has a love affair in Bali". Kalimat ini bukan hanya diucapkan beberapa kali namun juga dalam adegan yang berdekatan, sehingga memberikan penegasan simbolisasi bahwa Bali adalah tempat yang romantis, sehingga wisatawan yang datang ke Bali ratarata terlibat dalam suatu hubungan romantis. Kesan romantisme ini juga ditangkap dengan baik oleh penonton, seperti respon 'crazyfoggs' dari India (IMDb, 2010f) yang menyebutkan Bali terlihat seperti tempat yang romantis dan sesuai untuk liburan bersama pasangan.

Penggambaran sikap ramah juga dapat digolongkan kepada daya tarik emosional. Dalam film ini, keramahtamahan masyarakat tuan rumah diperlihatkan dengan baik. Salah satu dari keramahtamahan tersebut hadir dalam cara Ketut Liyer menerima dan berinteraksi dengan Liz. Ketut diceritakan tidak hanya sekedar menjadi seorang penyembuh yang menerima pasien, tetapi juga menjadi guru, teman, pembimbing, dan orang tua. Tokoh Ketut, yang digambarkan Liz tampak mirip seperti karakter Yoda dari film 'Star Wars', selalu diperlihatkan berbicara dengan intonasi yang tenang, sabar, ramah, dan beberapa kali juga melontarkan kalimat-kalimat yang lucu. Pada awal sekuen 'Love' ketika Liz kembali menemui Ketut Liyer, diperlihatkan Ketut tidak mengenalinya di awal perbincangan, namun seketika kemudian Ketut mengingatnya dan dia memberikan ekspresi senang karena Liz kembali menemuinya. Adegan ini juga memperlihatkan keramahtamahan. Menjadi 'diingat' oleh seseorang yang memang diharapkan, setelah sekian lama berselang, dapat menjadi suatu kebahagiaan tersendiri bagi sebagian orang. Beberapa kalimat Ketut Liyer yang menarik dan lucu sehingga dapat juga berperan sebagai daya tarik emosional adalah "see you later alligator" dan "smile with your liver".

Rutinitas kegiatan spiritual yang diajarkan oleh Ketut Liyer secara informatif dapat dikategorikan sebagai daya tarik rasional, namun bagaimana rangkaian kegiatan tersebut ditampilkan dalam film memberikan daya tarik emosional yang menunjukkan emosi yang ditimbulkan pada masingmasing bentuk kegiatan. Meditasi secara serius di pagi hari, diperlihatkan serius namun tidak membebani; kemudian, menikmati Bali di siang hari, diperlihatkan sebagai kegiatan rekreasi yang santai dan mendekati kegiatan warga lokal; dan terakhir, melakukan meditasi tersenyum di sore hari, diperlihatkan sebagai suatu kegiatan meditasi yang tenag dan mudah dinikmati.

Adegan penjelas rutinitas kegiatan spiritual dimulai dengan shot tiga orang perempuan Bali yang sedang sembahyang, wajah mereka tampak serius. Di latar terdengar suara Ketut Liyer dengan bahasa Inggrisnya yang tidak sempurna, "In morning, you do meditation from India, serious". Musik latar muncul dengan memperdengarkan musik tema yang memadukan 
suara gending Bali, kontra bass, dan flute yang memberikan kesan eksotik, santai, namun antusias. Hal ini mengesankan bahwa berdoa serius tidak selayaknya dibawa menjadi suatu beban. Selanjutnya Ketut melanjutkan "In day, you enjoy Bali". Terlihat gambar Liz sedang melakukan aktifitas di sebuah balai desa kemudian bersepeda menyusuri jalanan di Ubud. Musik latar kemudian berganti menjadi musik bertempo sedang-cepat dengan memperdengarkan suara terompet sebagai alat musik dominan disertai perpaduan suara perkusi, gitar bass, dan aksen-aksen suara rindik dengan intonasi staccato. Ritme musik ini menegaskan suasana yang lebih ceria, sesuai dengan suasana rekreasi di Ubud yang ingin disampaikan.

Pada bagian akhir penjelasan, Ketut mengatakan "End of day, you do new meditation. Very simple. Sit in silence and smile.". Shot kemudian memperlihatkan Liz sedang duduk dengan posisi meditasi di sebuah bale (Gambar 5.2). Suara musik seketika berhenti pada adegan ini, berganti dengan suara kicau burung di latar belakang. Matanya tertutup namun wajahnya tersenyum. Di belakangnya terlihat suasana rumah yang asri. Liz mengenakan baju blouse dan celana panjang longgar berbahan katun. Rambutnya dicepol rapi ke belakang. Kamera perlahan bergerak zoom in mendekati Liz sehingga ekspresi wajahnya menjadi lebih jelas. Pengaplikasian suara non musik dan memperjelas suara suasana sekitar mempertegas keadaan suasana yang tenang, sedangkan mimik wajah Liz yang tersenyum menampakkan suasana hati yang sedang menikmati sesi meditasi. Suasana sekitar yang diperlihatkan turut menguatkan suasana kegiatan spiritual yang tidak terlalu serius dan nyaman. Pakaian dan tata rias yang diaplikasikan pada adegan ini menambah kesan segar. Rambut Liz yang dicepol rapi dapat menjadikan perhatian penonton terfokuskan kepada ekspresi tersenyum Liz.

\subsection{Bujukan Moral pada Film 'Eat Pray Love'}

Konflik pribadi yang dikisahkan dalam 'Eat Pray Love' tampak seperti problematika yang dangkal dan tidak berdampak secara sosial, namun konflik yang dialami Liz Gilbert dapat dialami oleh banyak perempuan, ataupun mungkin saja laki-laki, di luar sana. Bagi penonton yang juga mengalami krisis emosional, kisah Liz dalam film ini juga dapat dikatakan memunculkan bujukan moral berupa motivasi untuk melakukan perjalanan yang sama, yaitu perjalanan untuk mencari keseimbangan dan kedamaian dalam diri masing-masing orang tersebut, sesuai dengan konflik mereka masing-masing. Kedamaian tersebut dapat berarti rehat sejenak dari padatnya rutinitas harian dan pekerjaan yang membawa kepenatan maupun problematika sosial dan emosional yang lebih mendalam. Liz Gilbert, dalam film, datang kembali ke Bali karena berharap di tempat itulah dia dapat menyelesaikan kegalauan yang melandanya. 


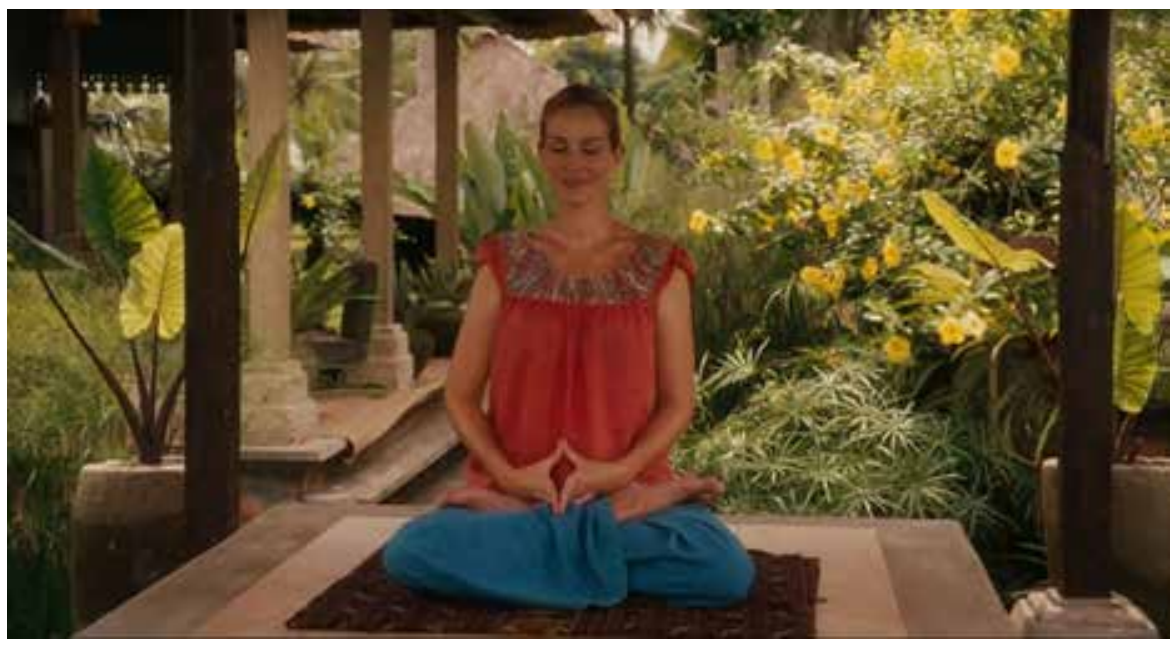

FILM 'EAT PRAY LOVE' PRODUKSI COLUMBIA PICTURE

Gambar 5.2 Shot Liz sedang melakukan meditasi tersenyum.

Kenyataan bahwa tokoh Liz adalah seorang perempuan tidak hanya dapat berperan secara emosional, namun juga dapat menjadi suatu daya tarik moral yang memperlihatkan bahwa perempuan pun dapat melakukan perjalanan seorang diri ke negara asing. Hal ini dapat berpengaruh kepada segmen wisatawan perempuan sebagai sebuah dukungan moral untuk melakukan perjalanan keluar dari zona nyaman di lingkungannya. Seperti yang diperlihatkan dalam film, tokoh Liz juga awalnya menjalani kehidupan di zona nyaman dengan melakukan hal-hal yang "normal" dan tanpa sadar melakukannya untuk memenuhi ekspektasi lingkungannya, termasuk dalam hal kehidupan berumahtangga. Belakangan, Liz mulai menyadari bahwa semua yang dia lakukan itu tidak benar-benar mencerminkan keinginannya, dan dia tidak lagi merasakan gairah dalam menjalani semua rutinitas tersebut. Liz tidak merasakan keseimbangan antara apa yang dia inginkan dan memenuhi ekspektasi orang lain terhadapnya. Dia ingin dapat memilih sesuatu untuk dirinya sendiri. Keputusannya bercerai dari suaminya dan kemudian memulai perjalanan setahun penuh ke tiga negara walaupun dengan dana terbatas adalah untuk menemukan keseimbangan itu. Kesadaran Liz, dalam cerita 'Eat Pray Love' ditampakan salah satunya juga dipicu oleh ramalan Ketut Liyer mengenai apa yang akan terjadi di rentang masa hidup Liz, sehingga Liz merasa bahwa dia perlu menjawab ramalan tersebut dengan mengambil tindakan.

Bagi penonton yang tergerak oleh kisah Liz dan merasakan kesamaan situasi, keputusan Liz untuk kembali ke Bali untuk belajar spiritualisme dari Ketut Liyer juga dapat menjadi dorongan maupun sokongan moral untuk melakukan perjalanan wisata spiritual yang sama. Bahwa Bali menawarkan suatu keunikan wisata spiritual yang dapat membantu pribadi-pribadi untuk 
menyelesaikan permasalahan batinnya. Keseimbangan yang didapatkan Liz ditampakkan sebagai suatu hasil dari proses belajar yang didapatkannya melalui interaksinya dengan orang-orang yang ditemuinya sepanjang perjalanan, namun tidak secara langsung disadarinya. Bali digambarkan sebagai tempat yang menawarkan suatu kondisi lingkungan alam dan sosial yang sesuai bagi Liz untuk mengambil esensi dari setiap pengalamannya untuk menemukan kedamaian di dalam dirinya sendiri. Pengalaman Liz yang didramatisasi dalam film ini dapat menjadi bujukan moral untuk melakukan peniruan atas perjalanan Liz tersebut dan mengunjungi Bali.

\section{Penutup}

Melalui analisis terhadap konten film 'Eat Pray Love' dapat dilihat bahwa pengerjaan sinematik yang baik sangat berperan dalam membentuk pesan promosi yang menguntungkan bagi destinasi pariwisata yang menjadi latar. Pada film 'Eat Pray Love' ini, Bali tidak saja diuntungkan dari segi narasi yang mengisahkan segmen 'Love' dengan latar Bali sebagai segmen yang memperlihatkan kegiatan liburan yang menyenangkan, namun kemampuan sineas dalam menangkap keutuhan suasana dengan mengaplikasikan unsurunsur yang tepat pada adegan yang tepat tampak dapat menghidupkan atmosfer suasana Bali dan menegaskan stereotipe suasana liburan yang mewakili Bali.

Perjalanan liburan Liz merupakan bujukan untuk berlibur ke Bali yang berperan seperti rekomendasi seorang wisatawan kepada wisatawan lainnya. Kehadiran film yang mengemas kisah nyata perjalanan Liz tersebut memvisualisasikan bujukan tersebut dengan menghadirkan daya tarik rasional, emosional, dan moral yang bekerjasama dengan baik tanpa saling bertentangan antara satu sama lainnya. Banyak bukti bahwa kunjungan wisatawan ke Ubud meningkat karena film dan buku Eat Pray Love, seperti ramainya kunjungan turis ke rumah Ketut Liyer (sampai dia meninggal tahun 2015) untuk diramal nasibnya seperti Liz. Jika itu kurang meyakinkan, yang jelas film Eat Pray Love dan novel biografis Gilbert telah menjadi promosi gratis yang luar biasa untuk Ubud khususnya dan Bali pada umumnya.

\section{Ucapan Terimakasih}

Penulis ingin mengucapkan terimakasih yang sedalam-dalamnya kepada Prof. Dr. I Nyoman Darma Putra, M.Litt., selaku pembimbing I, dan Dr. I Made Suradnya, SE. M.Sc., selaku pembimbing II, yang telah membimbing dengan sabar serta memberikan pengarahan yang memperkaya wawasan serta sudut pandang penulis dalam ranah promosi pariwisata yang menjadi topik dalam penelitian ini. Berkat bimbingan, pengarahan, serta motivasi tersebut, tesis dan artikel ini dapat terampungkan dengan hasil yang baik. Terimakasih juga penulis ingin ucapkan kepada Prof. Dr. Ir. Made Antara, 
M.S., Dr. Dewa Putu Oka Prasiasa, A.Par., M.M., dan Ni Made Sofia Wijaya, SST. Par., M.Par., Ph.D., selaku penguji tesis yang telah memberikan saran, masukan, dan koreksi, yang bermanfaat dalam penyempurnaan karya tulis tersebut.

\section{Daftar Pustaka}

Bali Echo. 2001. "Bali in Film: from The Documentary Films of Sanghyang and Kecak Dance (1926) to Bali Hai in Hollywood's South Pasific (1958)”, sumber: http:// michellechin.net/writings/o4.html Diakses: 7/9/2015

Connell, J. 2012. "Film Tourism - Evolution, progress and prospects". Tourism Management, 33, hal 1007-1029. [cited 6 April 2014]. Available from http:// ac.els-cdn.com/So261517712000404/1-s2.o-So261517712000404-main.pdf?_ tid=b3e25578-bcea-11e3-8bbf-oooooaacb35f\&acdnat=1396720377_ooo129ao o7ao5d5b3d22b3693240992a

Daily Mail. 2010. "Beautiful Bali: Eat, Pray Love, on Julia Robert Mystical Island", sumber: http://www.dailymail.co.uk/travel/article-1305177/Eat-Pray-LoveJulia-Roberts-Bali-island.html Diakses: 28/5/2015

Denver Post. 2010. "Travel Industry Courting "Eat, Pray, Love" Fans", sumber: http://www.denverpost.com/2010/o8/12/travel-industry-courting-eat-praylove-fans/ Diakses 30/7/2016

IMDb. 2010a. "Eat Pray Love", sumber: http://www.imdb.com/title/tto879870/ Diakses 16/11/2015

IMDb. 2010b. "A film to remember", sumber: http://www.imdb.com/title/ tto879870/reviews?start=110 Diakses: 30/3/2016

IMDb. 2010c. "Julia Robert in high form”, sumber: http://www.imdb.com/title/ tto879870/reviews?start=190 Diakses: 30/3/2016

IMDb. 2010d. "Emotionally profound”, sumber: http://www.imdb.com/title/ tto879870/reviews?start=190 Diakses: 30/3/2016

IMDb. 2010e. "Now I want to go to Bali”, sumber: http://www.imdb.com/title/ tto879870/reviews?start=210 Diakses: 30/3/2016

IMDb. 2010f. "A divorced and very confused woman goes in search of herself around the world and falls in love", sumber: http://www.imdb.com/title/tto879870/ reviews?start=190 Diakses: $30 / 3 / 2016$

Jezebel. 2010. "How Elizabeth Gilbert Ruined Bali", sumber: http://jezebel. com/5601522/how-elizabeth-gilbert-ruined-bali Diakses: 1/5/2016

Kim, S. 2012. "Audience Involvement and Film Tourism Experiences: Emotional Places, Emotional Experience”. Tourism Management. Vol. 33. Hal 387-396.

Kotler, P., dkk. 2010. Marketing for Hospitality and Tourism. New Jersey: Pearson Prentice Hall.

Morissan. 2010. Periklanan: Komunikasi Pemasaran Terpadu. Jakarta: Kencana.

Piliang, Y. A. 2012. Semiotika dan Hipersemiotika: Kode, Gaya dan Matinya Makna. Bandung: Matahari. 
Purwasito, A. 2006. Semiologi Komunikasi. Mediator. Vol. 7. No. 1. [cited 9 December 2015] Available from http://ejournal.unisba.ac.id/index.php/mediator/article/ view/1268/771.

Rotten Tomatoes. 2010a. "Eat Pray Love Reviews", sumber: http://www. rottentomatoes.com/m/eat_pray_love/reviews/?page=27\&type=user Diakses 4/4/2016.

Rotten Tomatoes. 2010b. "Eat Pray Love Reviews", sumber: http://www. rottentomatoes.com/m/eat_pray_love/reviews/?page=37\&type=user Diakses: 4/4/2016.

Rotten Tomatoes. 2010c. "Eat Pray Love Reviews", sumber: http://www. rottentomatoes.com/m/eat_pray_love/reviews/?page=46\&type=user Diakses: 5/4/2016.

Sharon, D. 1992. Tourism: An Introductory Text. Victoria: Edward Arnold Australia. Spirit Quest Tours. t.t. “Eat Pray Love Bali, Spiritual Bali Tour, Visit Bali”, sumber: https://spiritquesttours.com/eat-pray-love/ Diakses: 3/4/2016.

The Jakarta Post. 2010. "Bali Grows as World-class Spiritual Tourist Site", sumber: http://www.thejakartapost.com/news/2010/10/27/bali-grows-worldclassspiritual-tourist-site.html Diakses 30/7/2016.

Thwaites, T.,, dkk. 2011. Introducing Cultural and Media Studies: Sebuah Pendekatan Semiotik. Yogyakarta: Jalasutra.

Time. 2010. "Bali Travel Boom: Eat, Pray, Love Tourism”, sumber: http://content. time.com/time/magazine/article/o,9171,2011931,oo.html Diakses 28/5/2015.

Vagionis, N, M. Loumioti. 2011. Movies as a Tool of Modern Tourist Marketing. Tourismos: An International Multidisciplinary Journal Of Tourism, Volume 6, Number 2, Autumn 2011, pp. 353-362. [cited 29 October 2014]. Available from https://www.academia.edu/8064828/MOVIES_AS_A_TOOL_OF_ MODERN_TOURIST_MARKETING.

World Toddler. 2016. "Island of the Single White Female", sumber: http://www. worldtoddler.com/2016/o4/island-of-single-white-female.html

Diakses $1 / 5 / 2016$.

\section{Profil Penulis}

Rimalinda Lukitasari menyelesaikan studi magister di Program Studi Kajian Pariwisata Program Pascasarjana Universitas Udayana pada tahun 2016. Penulis memperoleh gelar diploma satu Bahasa Inggris dari UPT Lab Bahasa Universitas Udayana (2006) dan strata satu di bidang Sastra Inggris dari Fakultas Sastra Universitas Udayana (2010). Saat ini penulis menangani bagian komunikasi pemasaran di Tanamas Design and Development, sebuah perusahaan konsultan desain dan pengembangan di bidang arsitektur, interior, dan taman yang berbasis di Denpasar-Bali. Selain itu, penulis juga seorang microblogger yang turut aktif mempromosikan kuliner Indonesia melalui Instagram. Email: rimatanzil@yahoo. com 
I Nyoman Darma Putra adalah guru besar Fakultas Ilmu Budaya dan Ketua Program Studi Magister Kajian Pariwisata, Universitas Udayana. Darma menulis beberapa buku biografi tokoh pariwisata Bali dan menyunting beberapa buku, termasuk Pariwisata Berbasis Masyarakat Model Bali (2015) dan bersama Siobhan Campbell mengedit buku Recent Developments in Bali Tourism: Culture, Heritage, and Landscape in an Open Fortress (2015). Bersama Diah Sastri Pitanatri, Darma menulis buku Wisata Kuliner, Atribut Baru Destinasi Ubud (2016). Email: idarmaputra@ yahoo.com 